\title{
Komunikasi Bergerak Frekuensi 2.3 GHz Melewati Pepohonan Menggunakan Metode Giovanelli Knife Edge
}

\author{
Andrita Ceriana Eska \\ Fakultas Teknik, Universitas Jember \\ Jalan Kalimantan No. 37, Kampus Tegalboto Jember, Jawa Timur, Indonesia \\ Email korespondensi : andritacerianaeska@gmail.com
}

Dikirim 06 April 2016, Diperbaiki 24 April 2016, Diterima 05 Mei 2016

\begin{abstract}
Abstrak - Sistem komunikasi antara MS (Mobile Station) dan RBS (Radio Base Station) dengan frekuensi 2.3 GHz kondisi uplink, komunikasi yang terjadi ketika pengguna MS yang bergerak disepanjang trotoar terhadap RBS yang berada di tepi bagian atas gedung. Propagasi melewati pepohonan yang berada diantara kedua ruas jalan dan juga berada disepanjang trotoar, sehingga metode difraksi menggunakan single knife-edge dan Giovanelli knife-edge. Pada penelitian ini berfokus pada variasi ketinggian gedung dan daya pancar. Analisa ditunjukkan pada persentase daerah cakupan disepanjang lintasan MS. Persentase tersebut terjadi peningkatan dengan variasi daya pancar $20 \mathrm{dBm}$ hingga $40 \mathrm{dBm}$ yang diikuti peningkatan ketinggian gedung. Hasil penelitian, menunjukkan beberapa titik pada lintasan yang memiliki loss yang sangat besar, menjadikan sedikit peningkatan persentase daerah tercakup RBS. Pengaruh dari komunikasi tersebut diantaranya karena pepohonan, atmosfer, dan juga jarak komunikasi.
\end{abstract}

Kata kunci - Single-Knife-Edge, Giovanelli-Knife-Edge, $2.3 \mathrm{GHz}$, uplink, pepohonan

\begin{abstract}
The communication system between MS (Mobile Station) and RBS with frequency $2.3 \mathrm{GHz}$ uplink condition, the communication was happened when the user MS moved along of sidewalk toward RBS on the top edge of the building. The propagation through trees in the location between both roads and also along the sidewalk, so that diffraction method used single knife-edge and Giovanelli knife-edge. The research that communication focused at variation of high building and transmit power. Analysis shown in percentage coverage area along the path MS. That percentage was getting increase with the power transmit $20 \mathrm{dBm}$ until $40 \mathrm{dBm}$ with following an increase of high building. The result, shown in some point at path MS that have high loss, become less an increase percentage coverage area RBS. The influence from that communication is because tress, atmospheric, and also distance communication.
\end{abstract}

Keywords - Single-Knife-Edge,Giovanelli-Knife-Edge, $2.3 \mathrm{GHz}$, uplink, trees

\section{PENDAHULUAN}

Komunikasi MS (mobile station) terhadap RBS (Radio Base Station) menggunakan frekuensi 2.3 $\mathrm{GHz}$, dimana RBS juga dapat diletakkan pada gedung. Pengguna MS (Mobile Station) dapat berkomunikasi di jalan, trotoar, dan sebagainya. Keberadaan pepohonan disekitar trotoar dapat mempengaruhi sistem komunikasi. Keberadaan pepohonan pada ruas jalan, utamanya daerah perkotaan yang memiliki gedung di sepanjang jalan, menjadikan keberadaan gedung yang dekat dengan jalan dapat digunakan sebagai tempat RBS (Radio Base Station). Keberhasilan komunikasi juga dipengaruhi oleh penggunaan frekuensi, diantaranya atmosfer. Seperti penelitian yang melakukan pengukuran WiMax di daerah perkotaan [1]. Selain itu, keberadaan pepohonan disekitar daerah MS mempengaruhi komunikasi. Beberapa metode untuk menunjukkan mekanisme difraksi, seperti metode knife-edge. Salah satu penelitian yang menggunakan metode single knife edge [2], berfokus pada analisa loss difraksi antara pemancar dan penerima pada lingkungan urban canyon menggunakan frekuensi milimeter wave. Ada juga sebuah penelitian lain yang berfokus pada pemecahan masalah multiple knife edge[3]. Kedua penelitian tersebut penentuan gain difraksi dari knifeedge juga menerapkan perhitungan Fresnel zone.

Mekanisme difraksi knife edge diterapkan untuk perhitungan pengaruh pepohonan untuk sistem komunikasi MS terhadap RBS. Penelitian ini berfokus pada RBS yang diletakkan pada tepi gedung. Gedung memiliki berbagai macam ketinggian yang cukup untuk RBS, tanpa harus mendirikan tower.

Manfaat penelitian ini adalah untuk mengetahui besar pengaruh komunikasi pada kondisi uplink yang menggunakan frekuensi $2.3 \mathrm{GHz}$ saat melewati rintangan pepohonan, atmosfer, dan juga jarak 
komunikasi. Pengaruh ketinggian pepohonan yang berada pada tepi trotoar dan juga diantara kedua ruas jalan. Pepohonan tersebut juga diperhitungkan untuk komunikasi dari MS menuju RBS yang berada pada sisi ditepi gedung, dengan ketinggian gedung yang bervariasi. Komunikasi tersebut dapat diperhatikan akan menghadapi beberapa pohon, yang diperhitungkan menggunakan single knife edge, dan Giovanelli knife edge. Single knife edge digunakan untuk melewati satu rintangan pohon, dan Giovanelli knife edge lebih berfokus untuk dua rintangan pohon. Selama komunikasi, dilakukan penelitian dari variasi daya pancar, yaitu ketika $20 \mathrm{dBm}, 25 \mathrm{dBm}, 30 \mathrm{dBm}$, dan $40 \mathrm{dBm}$. Perbedaan daya pancar tersebut memberikan variasi dari seberapa besar persentase daerah yang tercakup selama komunikasi terjadi disepanjang lintasan. Variasi ketinggian gedung, juga mempengaruhi ketinggian RBS, semakin tinggi gedung maka peletakan RBS juga dapat diletakkan semakin tinggi. Penelitian yang dilakukan menggunakan beberapa variasi dari ketinggian gedung yaitu 15 meter, 20 meter, dan 25 meter. Sehingga dapat diketahui pengaruh dari ketinggian gedung terhadap persentase daerah yang tercakup.

Penelitian yang dilakukan bertujuan untuk mengetahui kualitas sinyal ketika dilakukan perubahan beberapa variasi daya pancar dan juga variasi dari ketinggian gedung, dimana ketinggian gedung tersebut sama dengan ketinggian RBS karena sesuai dengan peletakan RBS pada sisi tepi gedung. Selain itu untuk mengetahui besar persentase daerah tercakup pada lintasan MS. Komunikasi tersebut diperhitungkan menggunakan metode single knife edge, dan Giovanelli knife edge.

\section{METODOLOGI PENELITIAN}

\section{A. Model Sistem Komunikasi}

Model penelitian menggunakan kondisi jalan yang memiliki trotoar pada kedua ruas jalan. Pada kedua ruasnya terdapat pepohonan yang akan dilakukan perhitungan. Selain pepohonan, model sistem komunikasi untuk penelitian juga memperhitungkan keberadaan RBS pada gedung, seperti yang ditunjukkan pada Gambar 1.

Penelitian ini memodelkan sistem komunikasi dengan rintangan jalan raya yang dipenuhi dengan pepohonan, hal tersebut menjadikan komunikasi memiliki rintangan pepohonan. Pepohonan berada di tepi trotoar kedua ruas jalan. Ketinggian pepohonan memiliki keseragaman yaitu 7.5 meter, yang terdiri dari batang pohon setinggi 5 meter dan daun 2.5 meter. Jarak antar pohon di sepanjang trotoar sejauh 6 meter, seragam untuk semua jarak pepohonan tersebut. Pepohonan juga ada diantara kedua ruas jalan. Lebar setiap ruas jalan sejauh 6 meter, sehingga untuk kedua ruas jalan selebar 12 meter. Diantara kedua ruas juga terdapat pepohonan, dengan lebar 2 meter.
Pada Gambar 1, juga terdapat gedung yang berdiri pada ruas kanan. Penelitian ini melakukan variasi ketinggian gedung yaitu 15 meter, 20 meter, dan 25 meter. Pada sisi tepi gedung sebelah atas dan paling ujung terdapat RBS, sehingga komunikasi dapat terjadi. Keberadaan satu gedung hanya untuk menunjukkan penempatan RBS pada model, sehingga tidak menempatkan banyak gedung di sekitar model.

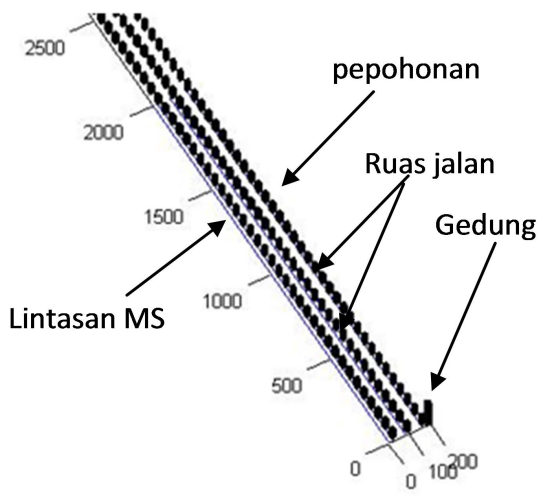

Gambar 1. Model Sistem Komunikasi Pada Jalan Raya Dengan Kondisi Pepohonan

Dari Gambar 1 tersebut, model sistem komunikasi untuk penelitian dilakukan dari MS yang berjalan di trotoar berjarak 0.5 meter dari sisi kiri trotoar terhadap RBS yang berada di atas gedung.

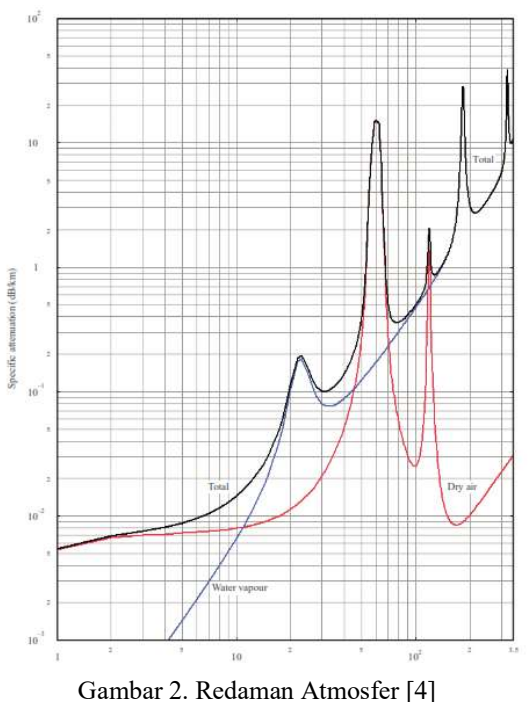

B. Atmosfer

Frekuensi $2.3 \mathrm{GHz}$ untuk sistem komunikasi juga dipengaruhi oleh atmosfer. Perhatikan pada Gambar 2 yang menunjukkan hubungan frekuensi dengan redaman atmosfer [4], karakteristik pressure: 1.013 $\mathrm{hPa}$, temperature: $15^{\circ} \mathrm{C}$, dan water vapour density: $7.5^{\mathrm{g}} / \mathrm{m}^{3}$. Karakteristik tersebut diperhitungkan untuk komunikasi pada penelitian. 


\section{Knife Edge}

Pergerakan MS pada lintasan atau trotoar, selama komunikasi menuju RBS dapat terhalang oleh adanya pepohonan. MS yang bergerak di sepanjang lintasan, pada titik tertentu selama komunikasi dapat saja tidak terhalang pepohonan sama sekali, terhalang satu pohon, maupun terhalang dua pohon. Difraksi untuk terhalang satu pohon, dapat ditunjukkan pada persamaan (1) [5]

$$
v=h \sqrt{\frac{2\left(d_{1}+d_{2}\right)}{\lambda d_{1} d_{2}}}
$$

Fresnel kirchhoff diffraction parameter, perhatikan persamaan 2, dan Gambar 3. [5]
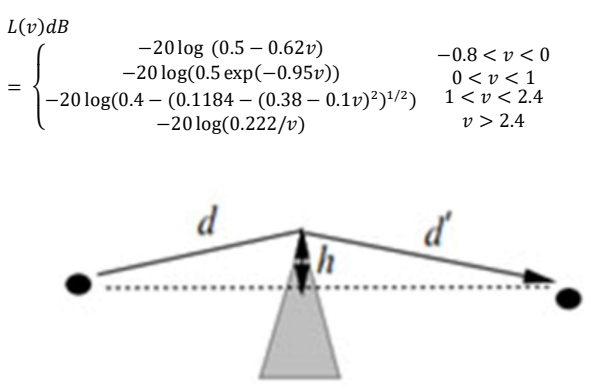

Gambar 3. Difraksi Single Knife-Edge [5]

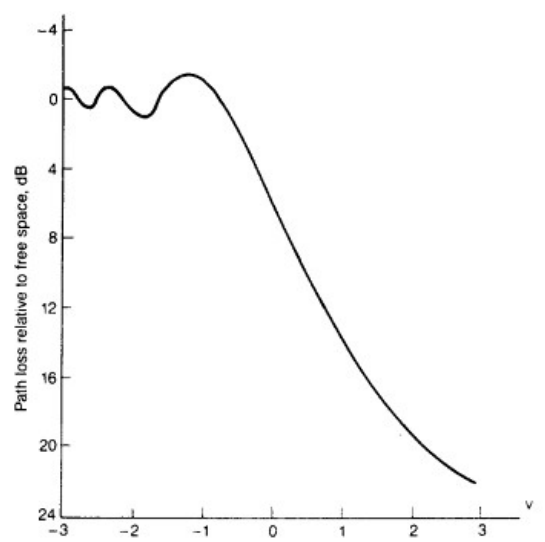

Gambar 4. Difraksi Single Knife Edge, Parameter v [6]

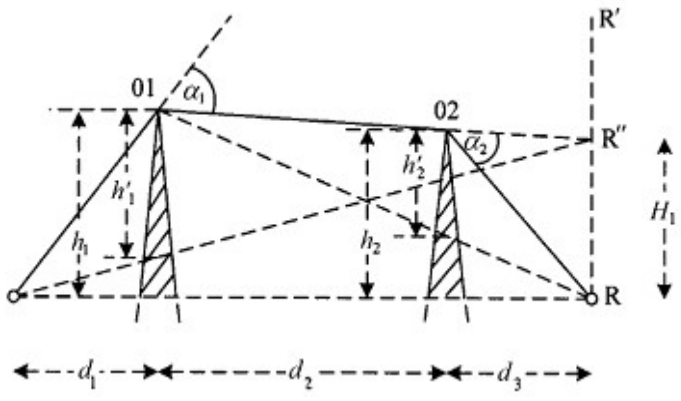

Gambar 5. Metode Giovanelli [6]

$$
\begin{aligned}
& h_{1}{ }^{\prime}=h_{1}-\frac{d_{1} H_{1}}{d_{1}+d_{2}+d_{3}} \\
& h_{2}{ }^{\prime}=h_{2}-\frac{d_{3} H_{1}}{d_{2}+d_{3}}
\end{aligned}
$$

Pada Gambar 4 ditunjukkan difraksi single knifeedge dari parameter $v$. Untuk difraksi yang terhalang dua pohon diperhitungkan menggunakan Giovanelli knife edge [6], perhatikan Gambar 5. Gambar tersebut merupakan metode Giovanelli knife-edge, dengan sumber ( $T$ ) dan penerima (R). Ketika sinar dari $T$ mencapai pengamatan di $\mathrm{R}^{\prime}$ setelah melalui sudut alfa, perhatikan pada persamaan (3-5), untuk mendapatkan parameter $\mathrm{v}$.

$$
\begin{aligned}
& L_{01}=f\left(d_{1}, d_{2}+d_{3}, h=h_{1}{ }^{\prime}\right) \\
& L_{02}=f\left(d_{2}, d_{3}, h=h_{2}{ }^{\prime}\right)
\end{aligned}
$$

\section{Pathloss}

Penelitian yang dilakukan pada kondisi uplink, dengan variasi daya pancar $20 \mathrm{dBm}, 25 \mathrm{dBm}, 30$ $\mathrm{dBm}$, dan $40 \mathrm{dBm}$, dan gain antenna RBS $3 \mathrm{~dB}$. Definisi pada persamaan (6) [7], diantaranya konstanta Boltzman (K), bandwidth (B), signal-tonoise ratio $(S / N)$ yang dibutuhkan untuk deteksi, dan noise figure (F). Asumsi penelitian sebagai berikut: noise figure sebesar $7 \mathrm{~dB}$, menggunakan bandwidth $200 \mathrm{MHz}$.

$$
\begin{aligned}
& N=k T_{S} B F \\
& L_{F S L}=-20 \log \left(\frac{\lambda}{4 \pi d}\right)
\end{aligned}
$$

Pada persamaan (7) [7], menunjukkan lamda $(\lambda)$, dan jarak komunikasi (d). Komunikasi tersebut menggunakan frekuensi $2.3 \mathrm{GHz}$. Selanjutnya dapat diakumulasi dengan pengaruh atmosfer, dan juga EIRP. Selanjutnya dapat menentukan daerah tercakup dari SNR pada lintasan MS atau pada trotoar.

\section{HASIL PENELITIAN}

Pada bagian ini menjelaskan hasil penelitian pergerakan MS di sepanjang trotoar yang berkomunikasi dengan RBS pada kondisi uplink, menggunakan variasi daya pancar mulai dari $20 \mathrm{dBm}$, $25 \mathrm{dBm}, 30 \mathrm{dBm}, 35 \mathrm{dBm}$, dan $40 \mathrm{dBm}$. Pada Gambar 6 menunjukkan hasil komunikasi dengan daya pancar $20 \mathrm{dBm}$ ketika ketinggian gedung 15 meter. Komunikasi tersebut mendapatkan rintangan pepohonan, yang diperhitungkan menggunakan pathloss, single knife-edge, Giovanelli knife-edge, dan pengaruh atmosfer. Dari gambar terdapat titik-titik untuk setiap satu meternya. Garis dengan SNR tertinggi, merupakan titik-titik tertentu pada lintasan MS ketika terjadi pathloss. Garis dengan SNR terendah dan garis lainnya, merupakan titik-titik tertentu pada lintasan MS ketika terhalang pepohonan. 
Untuk hasil dari variasi daya pancar $20 \mathrm{dBm}, 25$ $\mathrm{dBm}, 30 \mathrm{dBm}, 35 \mathrm{dBm}$, dan $40 \mathrm{dBm}$ ditunjukkan pada Gambar 7. Gambar tersebut menunjukkan komunikasi ketika variasi ketinggian gedung 15 meter. Ketika MS bergerak pada titik 353 meter pada lintasan MS atau trotoar, dengan daya pancar $20 \mathrm{dBm}$, tinggi gedung 15 meter, menghasilkan lintasan propagasi sejauh 355.16 meter, yang diakumulasi karena ketinggian satu pohon yaitu berada ditengah kedua ruas jalan, diperoleh SNR -14.15 dB. Pada titik yang sama dengan daya pancar $35 \mathrm{dBm}$ diperoleh SNR $0.85 \mathrm{~dB}$. Ketika MS bergerak pada titik 454 meter menghasilkan lintasan propagasi sejauh 455.72 meter, yang diakumulasi karena ketinggian satu pohon yaitu berada di trotoar dekat MS, diperoleh SNR 5.94 dB. Pada titik yang sama dengan daya pancar $35 \mathrm{dBm}$ diperoleh SNR $20.94 \mathrm{~dB}$. Ketika MS bergerak pada titik 1 meter pada lintasan MS, menghasilkan lintasan propagasi sejauh 25.54 meter, yang diakumulasi karena ketinggian pohon dua buah yaitu ditunjukkan dengan besar $v_{1}=-4.5$, dan $v_{2}=-5.1$. Pada titik tersebut dari besar $v_{1}$ dan $v_{2}$ diakumulasi berdasarkan freznel zone, sehingga dihasilkan gainknife-edge $0 \mathrm{dBm}$ dan SNR sebesar $37.69 \mathrm{~dB}$. Pada titik yang sama dengan daya pancar $35 \mathrm{dBm}$ diperoleh $52.69 \mathrm{~dB}$.

Hasil dari variasi daya pancar $20 \mathrm{dBm}$ sampai 40 $\mathrm{dBm}$ dengan ketinggian gedung 20 meter ditunjukkan pada Gambar 8. Untuk daya pancar $20 \mathrm{dBm}$, ketika MS bergerak pada titik 353 menghasilkan lintasan propagasi sejauh 355.30 meter dengan SNR -13.90 dB. Ketika MS bergerak pada titik 454 meter menghasilkan propagasi sejauh 455.83 meter dengan SNR $12.11 \mathrm{~dB}$. Ketika MS bergerak pada titik 1 meter menghasilkan propagasi sejauh 29.05 meter dengan SNR $36.58 \mathrm{~dB}$. Untuk daya pancar $40 \mathrm{dBm}$, ketika MS bergerak pada titik 353 menghasilkan SNR 6.09 $\mathrm{dB}$, titik 454 meter menghasilkan SNR $32.11 \mathrm{~dB}$, titik 1 meter menghasilkan SNR $56.59 \mathrm{~dB}$.

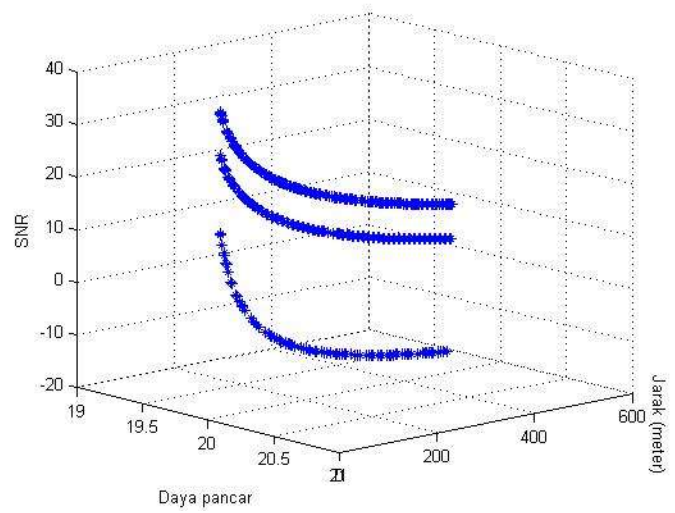

Gambar 6. Daya Pancar 20 dbm Dengan Ketinggian Gedung 15 m.

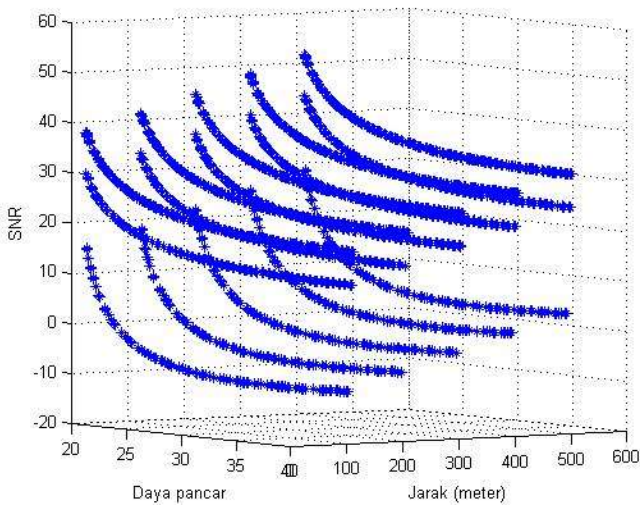

Gambar 7. Variasi Daya Pancardengan Ketinggian Gedung 15 m

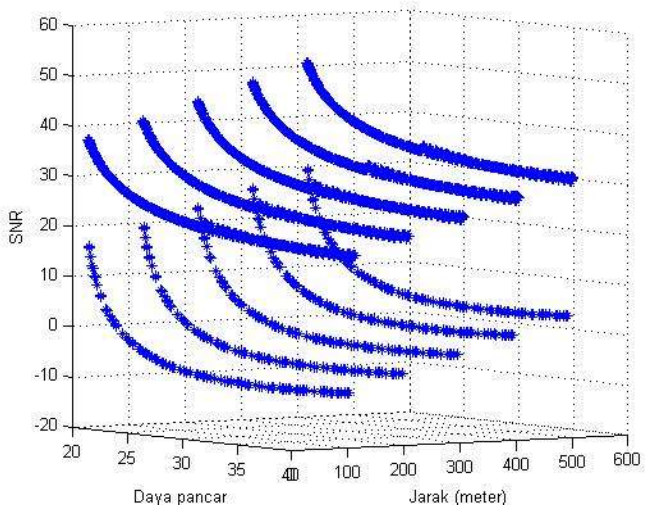

Gambar 8. Variasi Daya Pancardengan Ketinggian Gedung 20 m

Hasil dari variasi daya pancar $20 \mathrm{dBm}$ sampai 40 $\mathrm{dBm}$ dengan ketinggian gedung 25 meter ditunjukkan pada Gambar 9. Untuk daya pancar $20 \mathrm{dBm}$, ketika MS bergerak pada titik 353 menghasilkan lintasan propagasi sejauh 355.58 meter dengan SNR -13.65 dB. Ketika MS bergerak pada titik 454 meter menghasilkan propagasi sejauh 456.01 meter dengan SNR $12.62 \mathrm{~dB}$. Ketika MS bergerak pada titik 1 meter menghasilkan propagasi sejauh 33.19 meter dengan SNR $35.42 \mathrm{~dB}$. Untuk daya pancar $40 \mathrm{dBm}$, ketika MS bergerak pada titik 353 menghasilkan SNR 6.35 $\mathrm{dB}$, titik 454 meter menghasilkan SNR $32.62 \mathrm{~dB}$, titik 1 meter menghasilkan SNR $55.42 \mathrm{~dB}$.

Gambar 10 menunjukkan komunikasi MS ke RBS dengan daya pancar $20 \mathrm{dBm}$. Hasil tersebut merupakan salah satu hasil komunikasi seperti pada Gambar 5, namun pada Gambar 10 tersebut ditunjukkan dengan hasil SNR diatas $12 \mathrm{~dB}$. Untuk hasil lebih lengkapnya dapat dilihat pada Gambar 11. 


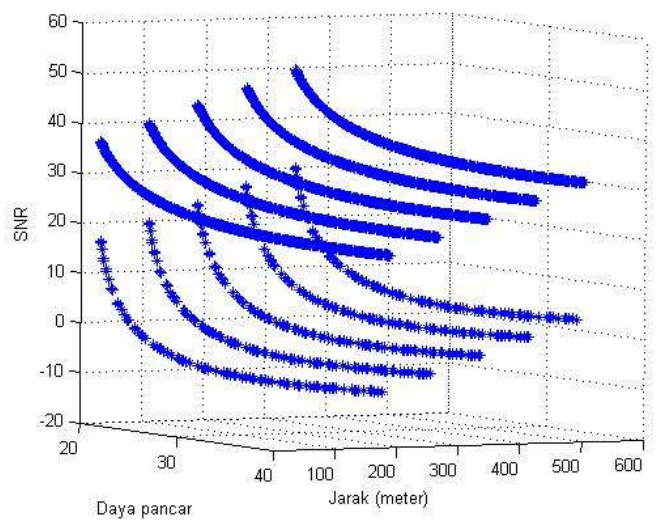

Gambar 9. Variasi Daya Tx Ketika Ketinggian Rx 25 m

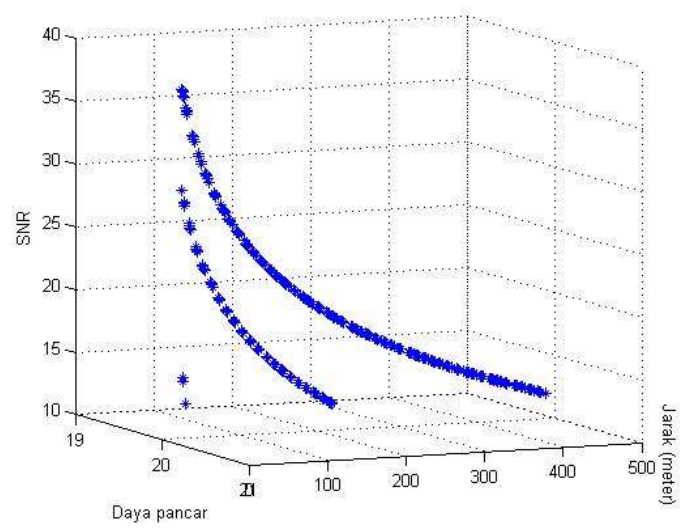

Gambar 10. Daya Pancar 20 Dbm Ketika Ketinggian Gedung 15 m SNR Diatas Threshold

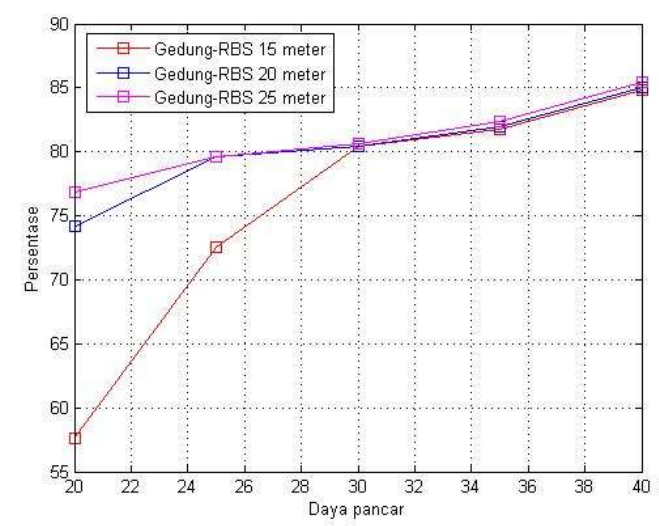

Gambar 11. Persentase Daerah Tercakup Dengan SNR Diatas Threshold

Gambar 11 menunjukkan persentase daerah yang tercakup dari titik-titik di sepanjang lintasan MS. Besar persentase diperoleh dari SNR yang didapatkan selama komunikasi terjadi di sepanjang lintasan. Gambar tersebut terdiri dari tiga garis yang menunjukkan ketinggian gedung mulai dari 15 meter, 20 meter, dan 25 meter. Ketika daya pancar $20 \mathrm{dBm}$, persentase terendah diperoleh saat ketinggian gedung 15 meter sebesar 57.6\%, ketika 20 meter sebesar 74\%, dan ketika 25 meter sebesar $76.8 \%$. Persentase daerah tercakup ketika daya pancar $40 \mathrm{dBm}$, dengan ketinggian gedung 15 meter sebesar 84.8\%, ketinggian gedung 20 meter sebesar $85 \%$, dan ketinggian gedung 25 meter sebesar $85.4 \%$.

\section{PEMBAHASAN}

Sistem komunikasi dari MS ke satu RBS menggunakan frekuensi $2.3 \mathrm{GHz}$, dimana pengguna MS yang berjalan di trotoar harus melalui kondisi lingkungan dengan banyak pohon, atmosfer, dan jarak komunikasi. Letak RBS berada pada sisi tepi gedung. Penelitian melakukan pengujian pada beberapa variasi daya pancar, dan juga beberapa variasi ketinggian gedung. Sebagai hasil akhirnya ditunjukkan dengan besar persentase daerah tercakup dari lintasan MS.

Sesuai dengan hasil penelitian yang telah dilakukan, salah satu data pergerakan MS yaitu jarak 454 meter, ketika daya pancar $20 \mathrm{dBm}$ dengan berbagai macam variasi ketinggian RBS yang terletak di atas tepi gedung. Untuk ketinggian gedung 15 meter diperoleh SNR 12.11, untuk ketinggian gedung 20 meter diperoleh SNR 12.11, untuk ketinggian gedung 25 meter diperoleh SNR 12.62. Dari data tersebut menunjukkan semakin tinggi keberadaan RBS maka terjadi peningkatan kualitas sinyal yang diterima oleh MS. Ketika daya pancar $40 \mathrm{dBm}$ dengan jarak pergerakan MS yang sama, untuk ketinggian gedung 15 meter didapat SNR 32.11, untuk ketinggian gedung 20 meter didapat SNR 32.11, dan untuk ketinggian gedung 25 meter didapat SNR 32.62. Dari data tersebut menunjukkan semakin tinggi keberadaan RBS maka terjadi peningkatan kualitas sinyal yang diterima oleh MS.

Berdasarkan hasil penelitian menunjukkan terjadi peningkatan kualitas SNR ketika daya pancar $20 \mathrm{dBm}$ hingga $40 \mathrm{dBm}$, seperti data berikut yang ditunjukkan pada pergerakan MS pada titik 454 meter dengan daya pancar $20 \mathrm{dBm}$ dan ketinggian gedung 25 meter menghasilkan SNR 12.62, ketika daya pancar $40 \mathrm{dBm}$ dan ketinggian gedung 25 meter menghasilkan SNR 32.62 .

Berdasarkan dari hasil penelitian, persentase daerah tercakup menunjukkan peningkatan yang dibuktikan dari beberapa data berikut. Ketika daya pancar $20 \mathrm{dBm}$ dengan ketinggian gedung 15 meter menghasilkan daerah tercakup sebesar 57.6 persen, dan untuk ketinggian gedung 25 meter, daerah tercakup sebesar 76.8 persen. Kemudian ketika daya pancar $40 \mathrm{dBm}$ dengan ketinggian gedung 15 meter, daerah tercakup sebesar 84.8 persen, dan untuk ketinggian gedung 25 meter, daerah tercakup sebesar 85.4 persen. Data tersebut menunjukkan semakin banyaknya daerah yang tercakup pada lintasan MS. Meningkatnya persentase MS selain pengaruh dari 
meningkatnya besar daya pancar, juga pengaruh dari ketinggian gedung dimana RBS berada.

\section{PENUTUP}

\section{A. Kesimpulan}

Dari penelitian, sistem komunikasi menggunakan frekuensi $2.3 \mathrm{GHz}$ pada kondisi uplink melewati rintangan pepohonan, atmosfer, dan jarak komunikasi, menunjukkan peningkatan daerah tercakup untuk komunikasi seiring dengan peningkatan daya pancar dan ketinggian gedung. Hal tersebut dibuktikan dari besarnya persentase daerah tercakup pada lintasan MS, seperti daya pancar $20 \mathrm{dBm}$ untuk ketinggian gedung 15 meter, daerah tercakupnya sebesar 57.6\%, hingga daya pancar $40 \mathrm{dBm}$ untuk ketinggian gedung 25 meter, daerah tercakupnya sebesar $85.4 \%$. Hal tersebut menunjukkan kualitas sistem komunikasi dari MS terhadap RBS menjadi lebih baik.

\section{DAFTAR PUSTAKA}

[1] C. Dalela, M.V.S.N. Prasad, P.K. Dalela, dan R. Saraf, "Analysis of WiMax Radio Measurements and Comparison with some Models Over Dense Urban Western India at $2.3 \mathrm{GHz}$," IEEE Antennas and Wireless Propagation, Vol. 10, 2011.

[2] B. Malila, O. Falowo, dan N. Ventura, "Millimeter Wave Small Cell Backhaul," AFRICON: IEEE, 2015.

[3] H. Oraizi, dan S. Hosseinzadeh, "Radio-WavePropagation Modeling in the Presence of Multiple Knife Edges by the Bidirectional Prabolic-Equation Method," IEEE Transactions on Vehicular Technology, vol. 56, no.3, May, 2007.

[4] ITU-R Radio Communication Sector of ITU (Attenuation by atmospheric gases), ITU-R P.67610, Geneva: Electronic Publication, 2013.

[5] A. Goldsmith, "Wireless Communications," Cambridge University Press, 2005.

[6] J.D. Parsons,"The Mobile Radio Propagation Channel Second Edition," England: John Wiley\&Sons, ISBN 0-470-84152-4, 2000.

[7] J.S. Seybold,"Introduction to RF Propagation," New Jersey: John Wiley\&Sons, 2005. 